\title{
Properties of meandrical geotextiles designed for the protection of soil against erosion
}

\author{
Joanna Grzybowska-Pietras ${ }^{1, *}$, Giang Nguyen ${ }^{1,2}$, Stanisława Przybyło $^{1}$, Monika Rom $^{1}$, \\ and Jan Broda ${ }^{1}$ \\ ${ }^{1}$ University of Bielsko-Biala, Faculty of Materials, Civil and Environmental Engineering, Willowa 2, \\ 43-394 Bielsko-Biała, Poland \\ ${ }^{2}$ University of Žilina, Faculty of Civil Engineering, Univerzitná 8215/1, 01026 Žilina, Slovakia
}

\begin{abstract}
Changes in climatic conditions in the world often affect the variability of water relations and soil erosion. Observed phenomena lead to removal of the most valuable soil surface layer from slopes, washout of minerals, deterioration of slope structure and also destruction of protective vegetation. Geotextiles are used to protect slopes from effects of erosion. Depending on the type of used raw material as well as production technology, geotextiles are used for long-term or temporary protection (biodegradable). Biodegradable geotextiles under influence of atmospheric factors undergo gradual decomposition. The substances released as a result of decomposition cause soil fertilization, which promotes development of protective vegetation. The aim of the research is to assess impact of exploitation time on selected physical, mechanical and hydraulic properties of innovative geotextiles in form of meandrically arranged Kemafil ropes made of wool and recycled fibers installed on slope in Jasienica Economic Zone in Międzyrzecze. The research was carried out in the Laboratory of Geosynthetics and Textile Products of the University of Bielsko-Biala in accordance with the applicable European standards. Nonwovens used for production of geotextiles were tested before installation, as well as after 6 and 12 months from their installation. Geotextiles reduce speed of rainwater flowing down from the surface of slope and store its excess. Waste raw materials used for production of geotextiles enable products effectively protecting slope against water erosion.
\end{abstract}

\section{Introduction}

Climate changes occurring more often in Poland adversely affect numerous existing construction objects. Strong insolation and sudden heavy rainfall as well as flowing water from slopes cause soil erosion, which have both environmental and economic consequences. In case of the absence of adequate protection of earth structure performance of these factors is the beginning of their destruction. This is particularly considerable in a period between completion of earthworks and permanent covering of the area with

${ }^{1}$ Corresponding author: jpietras@ath.bielsko.pl 
vegetation counteracting soil erosion. Therefore it is advisable to implement protection consisting in slope surface interception from harmful factors [1-3].

Geosynthetics have been used for protection and anti-erosion measure for many years. These products are used, among others, for construction of embankments or slopes from local soils characterized by poor mechanical properties. Geosynthetics are used in fact at all stages of investment implementation, and their proper application guarantees structures' correct operation and bring extension of their lifetime. In civil engineering, geosynthetics, including geotextiles perform a number of functions simultaneously e. g. in anti-erosion protection systems on slopes, geotextiles act as protection against structure slide, as a filter protecting subsoil against washout of soil particles (filtration, drainage) and also as surface protection. Geosynthetics mounted on a slope provide immediate erosion protection. Geosynthetics support protective vegetation by reducing washing out of seeds and fertilizers, as well as ensuring the proper microclimate for its germination and development. In the long term, in combination with protective vegetation, they provide a synergistic effect [4-6].

Spatial mats and polymers meshes as well as geocell systems made of nonbiodegradable materials of long-lasting life are applied for permanent erosion protection. In addition to geosynthetics from non-biodegradable materials; mats, meshes and nonwovens made of natural fibers are used for temporary erosion protection. Products made of these raw materials provide direct erosion protection for a limited period. These products are used most often as initiation protection for slopes with a small inclination, greened by means of hydroseeding [7-9].

The use of geosynthetics often allows solving difficult problems related to, among others, stability or bearing capacity of subsoil, filtration or drainage. The universality of using these products in a given investment process is very interesting. Numerous solutions with their application have been adopted as a standard and have become materials supporting structural elements. Numerous publications and designers' and contractors' experience acquired in engineering practice have confirmed the purpose and effectiveness of using these type of products, in cases when traditional methods are not very effective [8].

\section{Materials and methods}

\subsection{Materials}

In frame of implementation of the international project (CORNET), the University of Bielsko-Biala in cooperation with a German partner, undertook activities aimed at developing and creating meandrically arranged Kemafil ropes (Fig. 1), acting as protection of slope surface against erosion. Kemafil ropes were made of wool nonwoven fabric (sample No. 1) and non-woven fabric obtained from a mix of waste natural and synthetic fibers with grass seeds - RKL (sample No. 2). The ropes were meandrically arranged in segments of a width of $1.8 \mathrm{~m}$. The subsequent turns of meandrically arranged ropes were connected with regularly spaced five chains formed from five subsequent loops produced with knitting technique. Spread Kemafil meander on the slope surface can be seen in Fig. 2. 


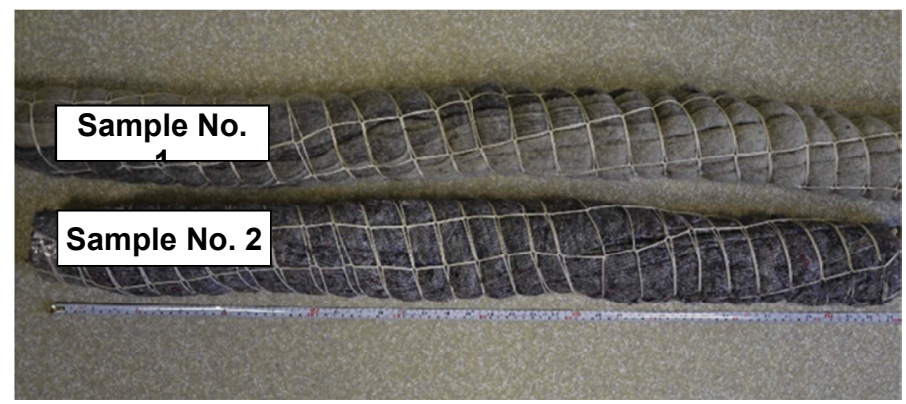

Fig. 1. The Kemafil ropes covered by knitted sheath [9].

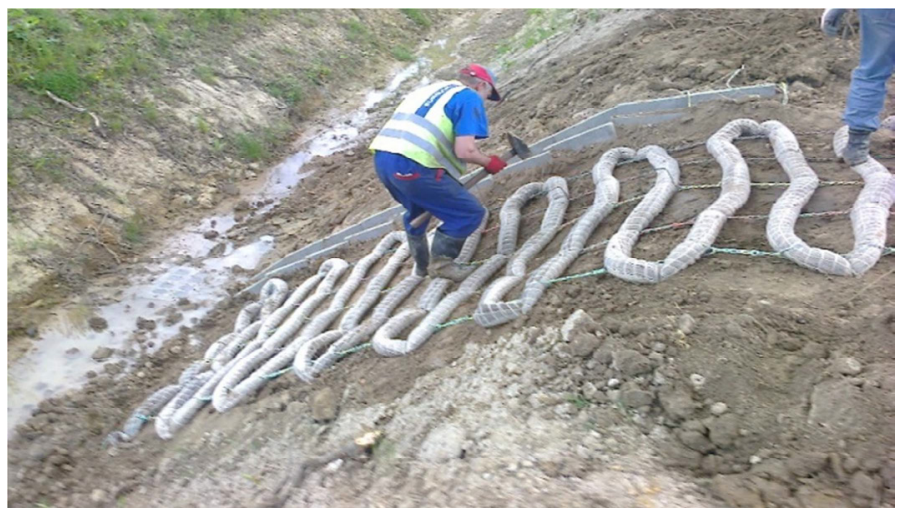

Fig. 2. Spread Kemafil meander on the slope surface.

\subsection{Research locations}

Prototype meandering geotextiles were installed in area of Jasienica Economic Zone in Międzyrzecze Dolne, located about $10 \mathrm{~km}$ from the centre of Bielsko-Biala. In the following, typical weather in Bielsko-Biala, based on a statistical analysis of historical hourly weather and model reconstructions from January 1, 1980 to December 31, 2016, posted in [10], will be introduced.

In Bielsko-Biala, the summers are comfortable and partly cloudy and the winters are freezing, dry, windy, and mostly cloudy. Over the course of the year, the temperature typically varies from $-5^{\circ} \mathrm{C}$ to $23^{\circ} \mathrm{C}$ and is rarely below $-14^{\circ} \mathrm{C}$ or above $29^{\circ} \mathrm{C}$.

The warm season lasts for 3.6 months, from May 23 to September 10, with an average daily high temperature above $19^{\circ} \mathrm{C}$. The hottest day of the year is August 6, with an average high of $23^{\circ} \mathrm{C}$ and low of $13^{\circ} \mathrm{C}$. The cold season lasts for 3.5 months, from November 22 to March 6, with an average daily high temperature below $5^{\circ} \mathrm{C}$. The coldest day of the year is January 19 , with an average low of $-5^{\circ} \mathrm{C}$ and high of $0^{\circ} \mathrm{C}$.

Concerning rainfall, Bielsko-Biala experiences significant seasonal variation in monthly rainfall. Rain falls throughout the year in Bielsko-Biala. The most rain falls during the 31 days centered around July 8, with an average total accumulation of 87 millimeters.

Concerning snowfall, Bielsko-Biala experiences some seasonal variation in monthly liquid-equivalent snowfall. The snowy period of the year lasts for 5.2 months, from November 2 to April 8, with a sliding 31-day liquid-equivalent snowfall of at least 3 millimeters. The most snow falls during the 31 days centered around January 1, with an average total liquid-equivalent accumulation of 9 millimeters. The snowless period of the year lasts for 6.8 months, from April 8 to November 2. The least snow falls around July 22, with an average total liquid-equivalent accumulation of 0 millimeters. 
The growing season in Bielsko-Biala typically lasts for 5.9 months (179 days), from around April 22 to around October 18, rarely starting before April 3 or after May 12, and rarely ending before October 1 or after November 4.

The monthly total precipitation for the research period from June 2015 to May 2018 was obtained from rainfall station Mazańcowice with station code 249180070 (5 km from our location) [11]. The average monthly total precipitation from June to December 2015 was $49.1 \mathrm{~mm}$; from January to December 2016 was $82.2 \mathrm{~mm}$; from January to December 2017 was $87.2 \mathrm{~mm}$ and from January to May 2018 was $36.2 \mathrm{~mm}$. The average monthly total precipitation for the whole period was $71 \mathrm{~mm}$, lower than above posted long-term values. The maximal and minimal monthly total precipitation for above mentioned period was $269.5 \mathrm{~mm}$ (September 2017) and $14.0 \mathrm{~mm}$ (August 2015), respectively.

Geotextiles have been used to protect the steep slope of the drainage ditch. The steep slope of the ditch with an inclination of $1: 1.5$ and length of 4-6 m were exposed to surface erosion caused by flowing down water during heavy rains, which grooved deep erosive channels with a depth of up to $0.5 \mathrm{~m}$ (Fig. 3).

In order to remediate effects of erosion, the slope of the ditch was leveled several times. However, these remedial works did not bring expected results, since after heavy rains, the slides and regrooving were observed.

Before geotextiles were installed, the ditch slope was profiled and the deep channels were filled and covered with soil. In addition, concrete open conduits were installed. Kemafil rope segments have been spread on the slope surface beside the conduit (Fig. 2). The segments were anchored to the upper edge and then attached to the slope surface using steel U-shaped pins. After installing ropes, the slope surface was covered with a soil layer (soil CL and CI; more information on soils will be introduced in the Chapters 3 and 4).

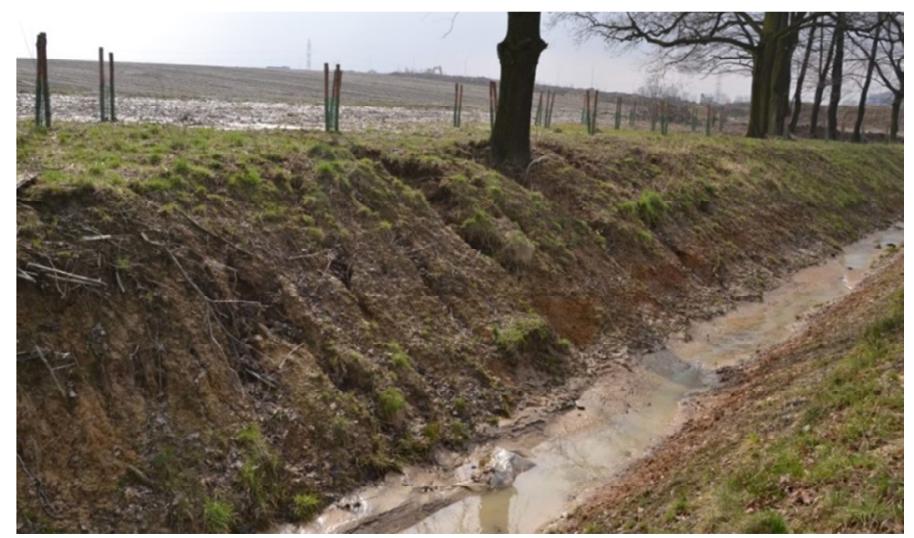

Fig. 3. The bank of the ditch with erosive channels before installation of the geotextiles [12].

\section{Research methodology}

During the research, soil samples were taken from the ditch slope (Fig. 4). Particle size distribution of the soils and their basic parameters were determined. Determination of soil particles size distribution was carried out in accordance with the BS 1377: 1990. Part 2 (wet sieving method and sedimentation by the hydrometer method) [13]. Soil parameters: water content $(\mathrm{w})$, liquid limits $\left(\mathrm{w}_{\mathrm{L}}\right)$ and plastic limits $\left(\mathrm{w}_{\mathrm{P}}\right)$ were also determined in accordance with mentioned standard. For determination of the liquid limit the Casagrande apparatus method (four-point method) was applied. Based on obtained values, soils classifications were carried out in accordance with the British Standard BS 5930:2015 [14]. 
The mass per square meter, thickness, tensile strength and elongation at break of nonwovens were measured in accordance with PN-EN ISO 9864: 2007 [15], PN-EN ISO 9863-1:2007 [16], and PN-EN ISO 10319:2010 [17] standards. Additionally, the static (CBR method PN-EN ISO 12236: 2006 [18]) and dynamic puncture (PN-EN ISO 13433: 2007 [19]) resistance were determined.

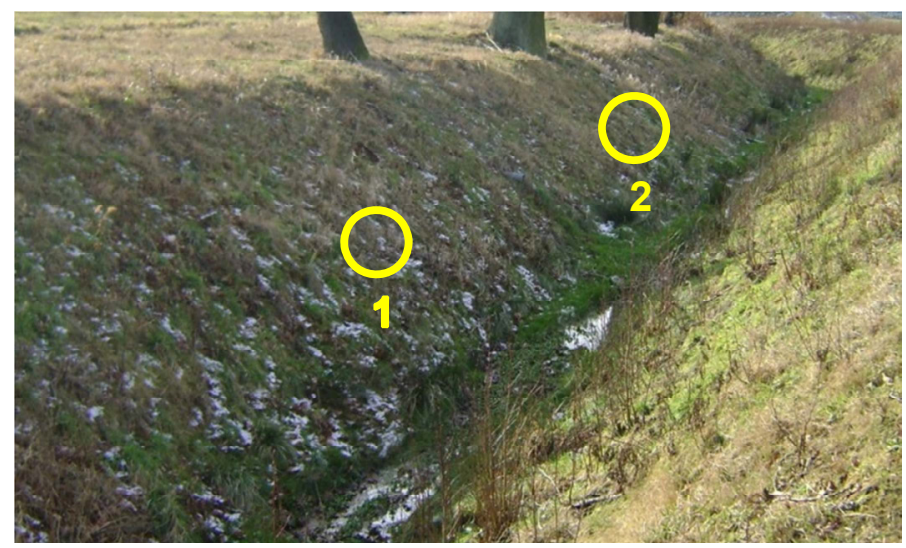

Fig. 4. Specimens locations.

In order to assess the impact of operating time on the hydraulic properties of Kamafil ropes, the tests of filtration properties of reference materials and materials dug out after 6 and 12 months from the slope were carried out. For the samples taken, the tests of water permeability normal to the plane without a load were tested in accordance with the harmonized standard PN-EN ISO 11058: 2011 [20]. In addition, after the installation of geotextiles in the ditch slope, the sites were regularly monitored. During the inspection, the effectiveness of ditch protection in various weather conditions was evaluated.

\section{Research results}

Properties of soils on slope are presented in Table 1.

Table 1. Properties of soils on slope in Międzyrzecze.

\begin{tabular}{|c|c|c|}
\hline \multirow{2}{*}{ Parameter } & \multicolumn{2}{|c|}{ Slope } \\
\cline { 2 - 3 } & $\begin{array}{c}\text { Specimen } \\
\text { No. } 1\end{array}$ & $\begin{array}{c}\text { Specimen } \\
\text { No. 2 }\end{array}$ \\
\hline Soil type & CL & CL \\
\hline water content $\mathrm{w}[\%]$ & 26.6 & 23.8 \\
\hline liquid limit $\mathrm{w}_{\mathrm{L}}[\%]$ & 33.5 & 33.8 \\
\hline plastic limit $\mathrm{w}_{\mathrm{P}}[\%]$ & 20.5 & 21.9 \\
\hline platicity index $\mathrm{I}_{\mathrm{P}}[\%]$ & 13.0 & 11.9 \\
\hline
\end{tabular}

After the installation of the ropes the condition of the ditch was regularly monitored. Immediately after installation on the banks of the ditch a network of micro-dams created from the meandrically arranged ropes was observed. The ropes slowed down the flow of water and reduced the transport of the soil along the slope. During six and twelve months of exploitation no erosive channels on the surface of the banks of the ditch were formed and no sliding of the slope was observed (Fig. 5) [21]. 


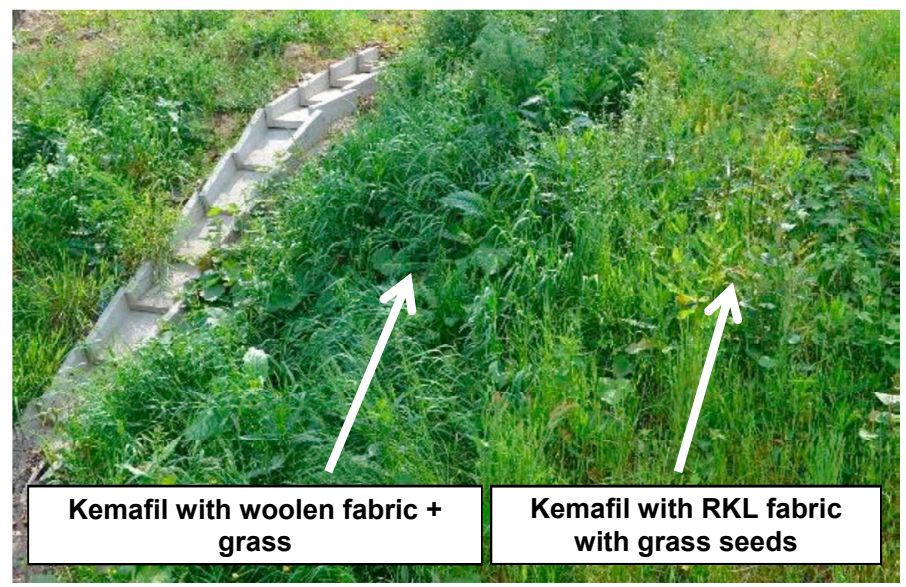

Fig. 5. The state of protected ditch bank one year after installation of the geotextiles [21].

The most intensive grass growth was recorded in places protected by woolen Kemafil ropes. The plants grown on the wool geotextiles had an intense dark green colour, much darker than the plants growing in other parts of the bank. The thick plants cover that grown on the ditch bank served as an effective protection against erosion. The system of plant shoots slowed down the surface runoff, while the root system favoured the infiltration of the water into the deeper layers of the ground [21].

Based on results of the tests, it was found that the materials used for the production of ropes undergo gradual biodegradation. In the case of wool nonwoven (Fig. 6) a very significant reduction in the value of all analyzed parameters was observed. In the case of nonwoven fabrics made of recycled fibers, it was found that the influence of operating time had a small effect on the change of its selected mechanical features (Fig. 7).

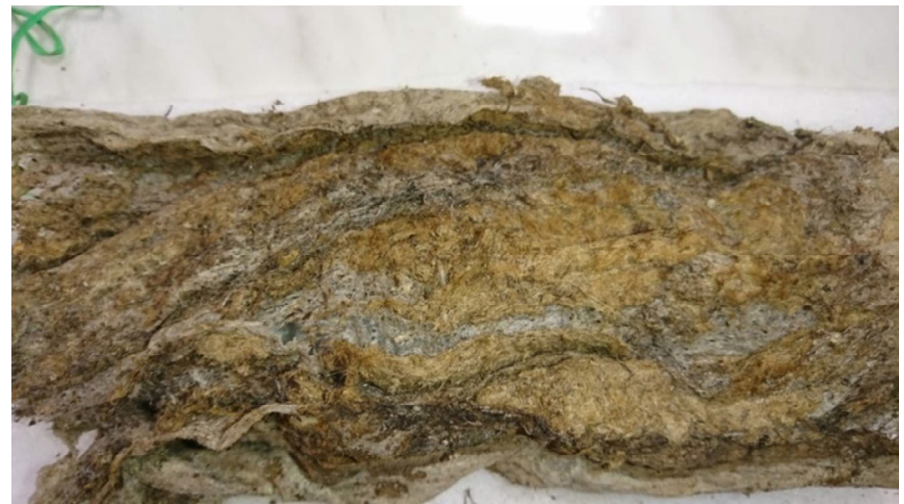

Fig. 6. View on woolen Kemafil rope after 12 months from installation. 


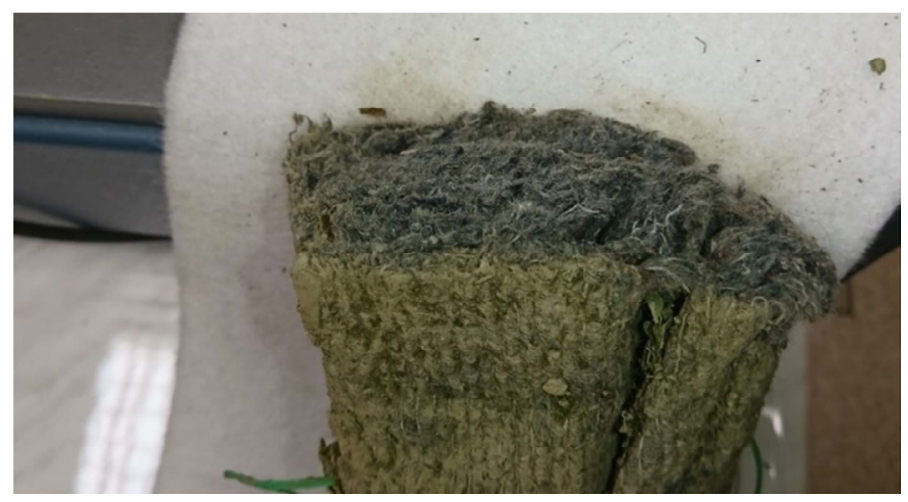

Fig. 7. View on RKL rope after 12 months from installation.

Mechanical parameters of geotextiles forming Kemafil ropes taken from slope are introduced in Tab. 2.

Table 2. Mechanical parameters of the geotextiles used for the production of the geotextiles [21].

\begin{tabular}{|c|c|c|c|c|c|}
\hline \multirow{3}{*}{$\begin{array}{c}\text { Material } \\
\text { type }\end{array}$} & \multirow{2}{*}{ Months } & Tenacity & $\begin{array}{c}\text { Elongation } \\
\text { at break }\end{array}$ & $\begin{array}{c}\text { Static } \\
\text { puncture } \\
\text { resistance }\end{array}$ & $\begin{array}{c}\text { Dynamic } \\
\text { puncture } \\
\text { resistance }\end{array}$ \\
\cline { 2 - 6 } & & {$[\mathrm{kN} / \mathrm{m}]$} & {$[\%]$} & {$[\mathrm{kN}]$} & {$[\mathrm{mm}]$} \\
\hline \multirow{3}{*}{ wool } & 0 & 0.67 & 40 & 0.16 & 32 \\
\cline { 2 - 6 } & 6 & 0.48 & 28 & 0.14 & 38 \\
\hline \multirow{3}{*}{ recycled } & 12 & 0.05 & 24 & - & - \\
\cline { 2 - 6 } & 0 & 3.3 & 35 & 0.53 & 29 \\
\cline { 2 - 6 } & 6 & 3.2 & 28 & 0.45 & 34 \\
\hline
\end{tabular}

After the first 6 months after installation, the strength of Kemafil ropes made of wool fibers was reduced by $30 \%$ compared to the initial strength $0.67 \mathrm{kN} / \mathrm{m}$. After one year, the strength of the wool nonwoven being the structural skeleton of the rope was small and barely reaches a value of $0.05 \mathrm{kN} / \mathrm{m}$. Such a low tenacity compared to the initial sample is the result of intensive biodegradation of wool fibers in the nonwoven fabric. In the case of assessment of operating time impact on the static and dynamic puncture resistance of wool fabric, the largest decrease in the analyzed parameters occurs after the sixth month from the installation on the site (Tab. 2).

Geotextile used for the production of Kemafil ropes from recycled synthetic fibers with a small admixture of natural fibers (RKL) had a strength of $3.3 \mathrm{kN} / \mathrm{m}$ before being installed on the slope. After 6 months, the strength decreased by only $0.1 \mathrm{kN} / \mathrm{m}$. After 1 year, the strength was reduced by only $7 \%$ compared to the initial strength. At the same time, no profound changes were observed in the structure of the Kemafil rope (Fig. 7). It is noted that the outer layer is very colmated, and the deeper geotextile layers are not affected.

In order to determine changes in filtration properties of Kemafil ropes and process of colmatation, depending on the time of exploitation, tests of water permeability normal to the surface of fabric (flow rate indicator) for cover layer directly contacted with soil were carried out.

Tests were carried out in accordance with harmonized standards [20]. Obtained results are introduced in Tab. 3 and also in Fig. 8, 9. 
Table 3. The results of the measurement of water permeability characteristics normal to plane of nonwovens.

\begin{tabular}{|c|c|c|c|}
\hline \multirow{3}{*}{$\begin{array}{c}\text { Number } \\
\text { of months }\end{array}$} & \multirow{2}{*}{$\begin{array}{c}\text { Water permeability } \\
\text { normal to plane } \\
\text { (filtration speed) }\end{array}$} & \multicolumn{2}{|c|}{ Material type } \\
\cline { 3 - 4 } & $\mathbf{X}[\mathbf{m} / \mathbf{s}]^{*} \mathbf{1 0}$ & Woollen fabric & $\begin{array}{c}\text { Fabric from } \\
\text { recycling RKL }\end{array}$ \\
\hline \multirow{3}{*}{0} & $\mathrm{~S}[\mathrm{~m} / \mathrm{s}]^{*} 10^{-3}$ & $\mathbf{7 0 . 6 1}$ & $\mathbf{4 0 . 4 2}$ \\
\cline { 2 - 4 } & $\mathrm{V}[\%]$ & 17.41 & 4.09 \\
\cline { 2 - 4 } & $\mathbf{X}[\mathbf{m} / \mathbf{s}]^{*} \mathbf{1 0}^{-3}$ & 24.58 & 10.02 \\
\hline \multirow{3}{*}{6} & $\mathrm{~S}[\mathrm{~m} / \mathrm{s}]^{*} 10^{-3}$ & $\mathbf{4 4 . 3 6}$ & $\mathbf{2 8 . 0 3}$ \\
\cline { 2 - 4 } & $\mathrm{V}[\%]$ & 7.78 & 7.84 \\
\cline { 2 - 4 } & $\mathbf{X}[\mathbf{m} / \mathbf{s}]^{*} \mathbf{1 0}^{-3}$ & 9.67 & 9.74 \\
\hline \multirow{3}{*}{12} & $\mathrm{~S}[\mathrm{~m} / \mathrm{s}]^{*} 10^{-3}$ & $\mathbf{4 2 . 1 4}$ & 2.21 \\
\cline { 2 - 4 } & $\mathrm{V}[\%]$ & 4.71 & 8.45 \\
\cline { 2 - 4 } & & 11.18 & \\
\hline
\end{tabular}

where: X-average value, S- standard deviation, V- coefficient of variation

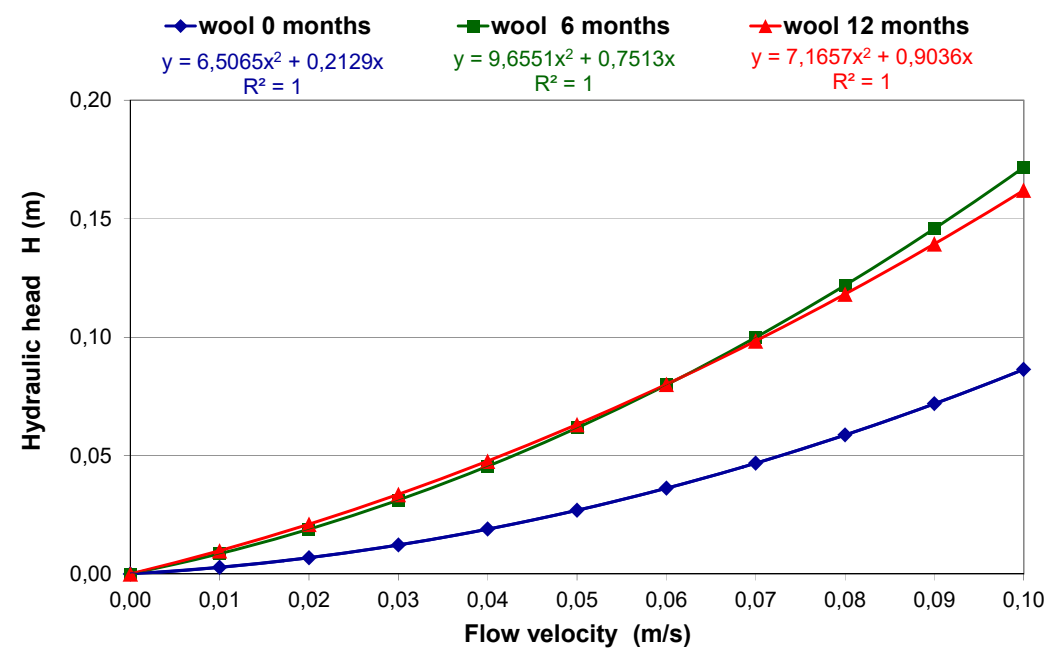

Fig. 8. Influence of the time of exploitation nonwovens wools on water permeability normal to the plane.

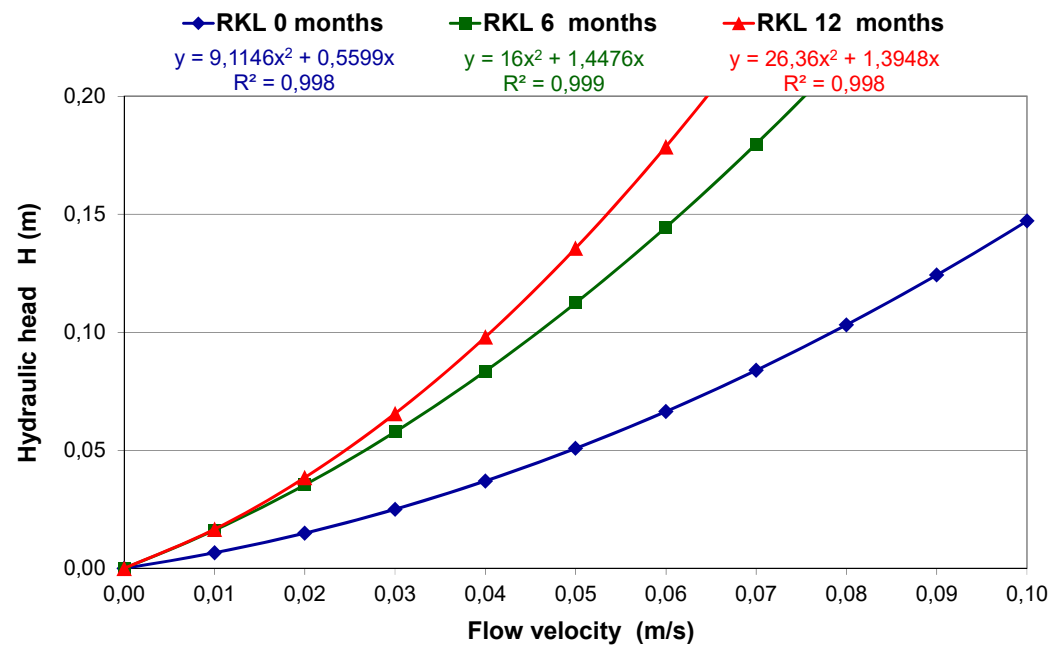

Fig. 9. Influence of the time of exploitation geonwovens RKL on water permeability normal to the plane. 
Analyzing the obtained tests results of influence of exploitation time on filtration properties of the outer layer of rope, one can observe that the greatest decrease in water permeability occurs in the first 6 months after installation, regardless of the type of material used.

The initial speed of water flow through geotextile from wool was approx. $71 \mathrm{~mm} / \mathrm{s}$. After six months, this value decreased by $37.2 \%(44.36 \mathrm{~mm} / \mathrm{s})$. After another 6 months ( 1 year) the permeability of the water normal to the plane decreased by only $2.22 \mathrm{~mm} / \mathrm{s}$.

A similar situation was observed in the case of outer layer from recycled synthetic fibers RKL. The initial water flow rate was $40.42 \mathrm{~mm} / \mathrm{s}$. After 6 months from installation, the discussed parameter was $28.03 \mathrm{~mm} / \mathrm{s}$ - a decrease by approximately $31 \%$. In the following 6 months, the water flow rate was recorded at $26.04 \mathrm{~mm} / \mathrm{s}$. In addition, mechanical and biological colmatation was visible on outer layer of the RKL. Clogging of the material by soil particles significantly affected water permeability in the outer layer of the product (Fig. 7). This was due to the fact that RKL fabric was subjected to atmospheric factors such as water (rain, snow) and soil, which caused smear of examined material and this is also associated with intensive development of vegetation root system.

\section{Conclusions}

There are a number of methods of erosion protection of slopes, which are constantly exposed to unfavorable weather conditions (rain, wind). Water erosion is one of the biggest problems associated with slopes protection against erosion. The streams of water and raindrops destroy slope surface. Intense rainfall very often washout (flush down) grass seeds covering slope, before they can germinate and root. The results of the research presented in this article confirm the possibility of using natural and synthetic raw materials available on the Polish market to produce Kemafil ropes.

Comparing obtained results, it can be noticed that regardless of the type of material used the largest decrease in water flow capacity is recorded in the first six months after installation. Obtained tests results of mechanical properties confirm possibility of using woolen Kemafil ropes as products of short-term use for anti-erosion protection.

Acknowledgments. The authors gratefully acknowledge the funding by ERANET-CORNET consortium under the international research project PROGEO 2 "Geotextiles from Sustainable Raw Materials and Textile Waste, New Mobile Production Technology and New Application Fields in Drainage and Hydraulic Engineering ” DZP/CORNET/1/20/2017.

\section{References}

1. C. Lipski, R. Kostuch, Infrastruktura i ekologia terenów wiejskich, 3, (2005)

2. P. Bozek, J. Janus, J. Taszakowski, A. Glowacka, IOP Conf. Series: Earth and Environmental Science 44042024 (2016)

3. L. Wysokiński, Awarie budowlane 2011 (2011)

4. E.Koda., P. Osiński., M. Głażewski, Sci. Rev. Eng. Env. Sci. 4 (50), 36-47 (2010)

5. R. Karpurapu, Indian Geotech. J. 47(1), (March 2017)

6. J. Kalibová, L. Jacka, J. Petru, Solid. Earth. 7, (2016)

7. K. Ayuba, E.S. Olorunnaiye, J. Rickson, Jorind 12, (2014)

8. S. Chaudhuri, R. Chakraborty, P. Bhattacharya, Iran Polym. J. 22, (2013)

9. J. Broda, A. Gawłowski, R. Laszczak, A Mitka, S. Przybyło, J. Grzybowska-Pietras, M. Rom, Geotext. Geomembr. 45, (2017) 
10. https://weatherspark.com/y/84987/Average-Weather-in-Bielsko-Biala-Poland-YearRound

11. https://dane.imgw.pl/data/dane_pomiarowo_obserwacyjne/dane_meteorologiczne/miesi eczne/opad/

12. J.Grzybowska-Pietras, J.Broda, S.Przybyło, M.Rom, R.Laszczak, A.Mitka, IMIG,4, (2015)

13. BS 1377, 1990. Part 2, Methods of test for soils for civil engineering purposes. Part 2. Classification tests, London, British Standards Institution (1990)

14. BS 5930, 2015. Code of practice for ground investigations, London, British Standards Institution (2015)

15. PN-EN ISO 9864:2007, Geosynthetics - Test method for the determination of mass per unit area of geotextiles and geotextile-related products (in Polish), Warsaw, Polish Committee for Standardization (2007)

16. PN-EN ISO 9863-1:2007: Geosynthetics - Determination of thickness at specified pressures - Part 1: Single layers (in Polish), Warsaw, Polish Committee for Standardization (2007)

17. PN-EN ISO 10319:2010 Geosynthetics - Wide-width tensile test (in Polish), Warsaw, Polish Committee for Standardization (2010)

18. PN-EN ISO 12236: 2006 Geosynthetics - Static puncture test (CBR test) (in Polish), Warsaw, Polish Committee for Standardization (2006)

19. PN-EN ISO 13433: 2007 Geosynthetics - Dynamic perforation test (cone drop test) (in Polish), Warsaw, Polish Committee for Standardization (2007)

20. PN-EN ISO 11058:2011 Geotextiles and geotextile-related products - Determination of water permeability characteristics normal to the plane, without load (in Polish), Warsaw, Polish Committee for Standardization (2011)

21. J. Broda, J. Grzybowska-Pietras, A. Gawłowski, M. Rom, S. Przybyło, R. Laszczak , Procedia Eng. 200 (2017) 